\title{
Nucleoli in the Oocytes of Some Arachnids
}

\author{
Madan Lal Sareen \\ Department of Zoology, Panjab University, Chandigarh, India
}

Received March 26, 1966

\section{Introduction}

A good deal of information is available about nucleoli in various animal cells (Caspersson 1950, Vincent 1955, Brachet 1957, 1960. Swift 1959, Sirlin 1961). Nath (1925) observed an active nucleolus which emits nucleolar extrusions in young oocytes of Buthus judaicus and Euscorpius napoli and an inactive one in Palamnaeus fulvipes and P. swammerdami. Recently I have dealt with the morphology and cytochemistry of oocytes in arachnids (Sareen 1961, 1962, 1963, 1964, 1965a, b, c). The present communication gives detailed account of nucleoli in oocytes of some arachnids.

\section{Material and technique}

Ovaries of the following eleven species of arachnids belonging to eight genera have been employed in the current study. Buthus hendersoni Pocock, B. macmahoni Pocock, B. tamulus Pocock (Scorpionida: Buthidae), Palamnaeus fulvipes Koch, P. bengalensis Koch (Scorpionida: Scorpionidae), Hyalomma aegyptium (Linn.), Argas persicus (Oken) (Acarina: Ixodidae), Lycosa chaperi Simon (Araneae: Lycosidae), Crossopriza lyoni (Blackwall) (Araneae: Pholcidae), Melanopa unicolor Roewer (Opiliones: Phalangidae), Diplotemnus insolitus Chamberlin (Chelonethida: Atemnidae).

Fixing fluids and histochemical tests employed are summarized in Table 1.

\section{Observations}

A single nucleolus is present in Buthus and Palamnaeus oocytes (Figs. 1-5). The nucleolus in Palamnaeus measures about $5.0 \mu$ whereas in Buthus it is about $12.0 \mu$. The yolk synthesis in Buthus seems to depend upon nucleolar activity (Figs. 1 to 4). In Palamnabus, only Zenker/haematoxylin preparations reveal some nucleolar budding (Fig. 5).

In an oocyte (about $24.0 \mu$ ) of Argas (Fig. 6) there is seen a single nucleolus (about $11.0 \mu$ ). Occasionally there are two nucleoli, a small (about $1.5 \mu$ ) and a large (about 5.6 $\mu$ ) in oocyte measuring about $15.0 \mu$ (Fig. 7). In Hyalomma oocyte (about $35.0 \mu$ ) there are as many as eight nucleoli (Figs. 8, 9) out of which one or two are larger (about $3.6 \mu$ ) than the others (about 1.8 $\mu$ ). With the advancement of vitellogenesis the nucleoli decrease in number, and one or two nucleoli are generally left in the well developed oocyte. In Hyalomma and Argas, the nucleoli in the young oocytes bud off fragments into the nucleoplasm; the fragments ultimately pass into the ooplasm (Fig. 10). The nucleolar buds in the nucleoplasm and the circumnuclear ooplasm are larger than those seen at the peripheral ooplasm. 


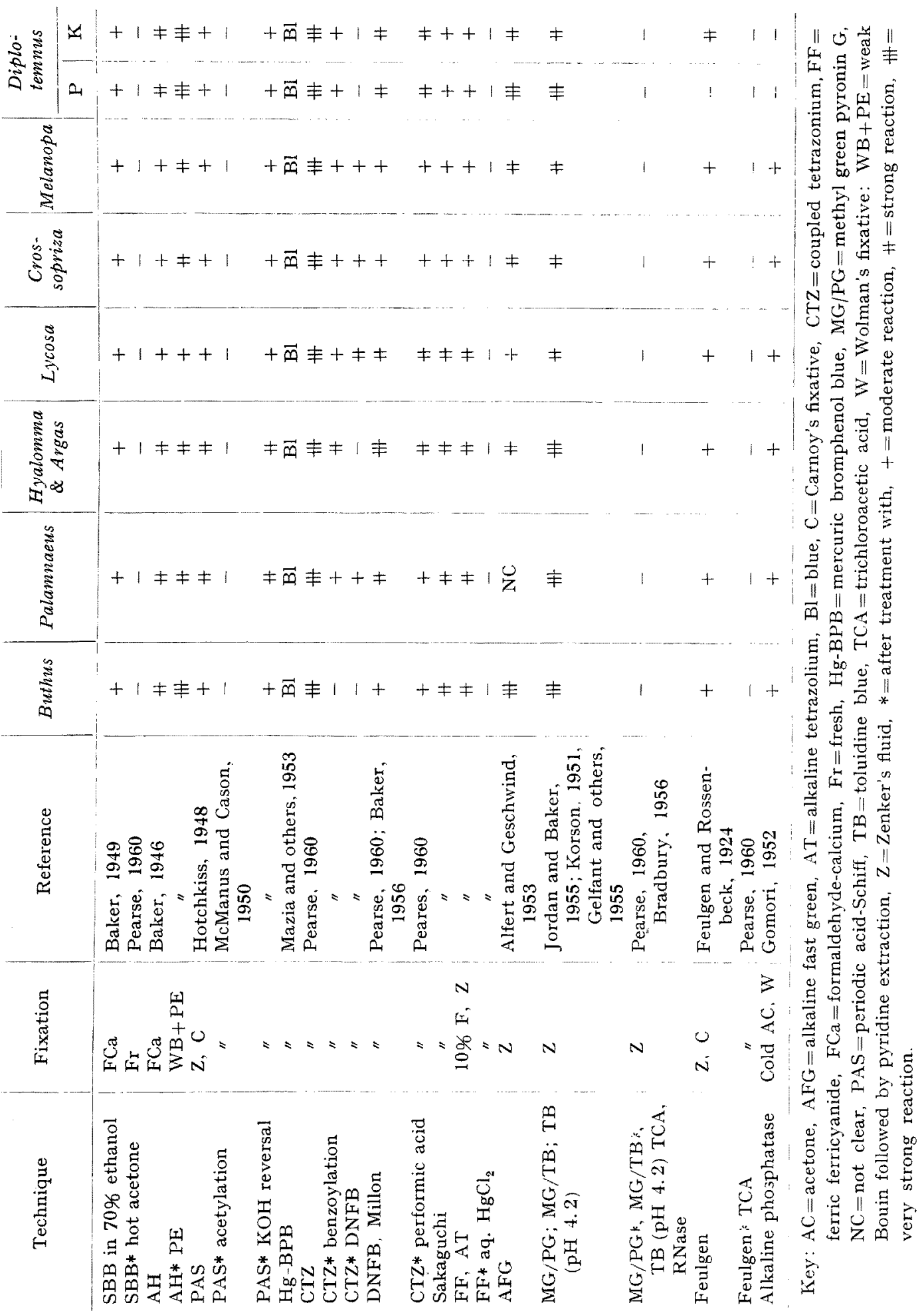



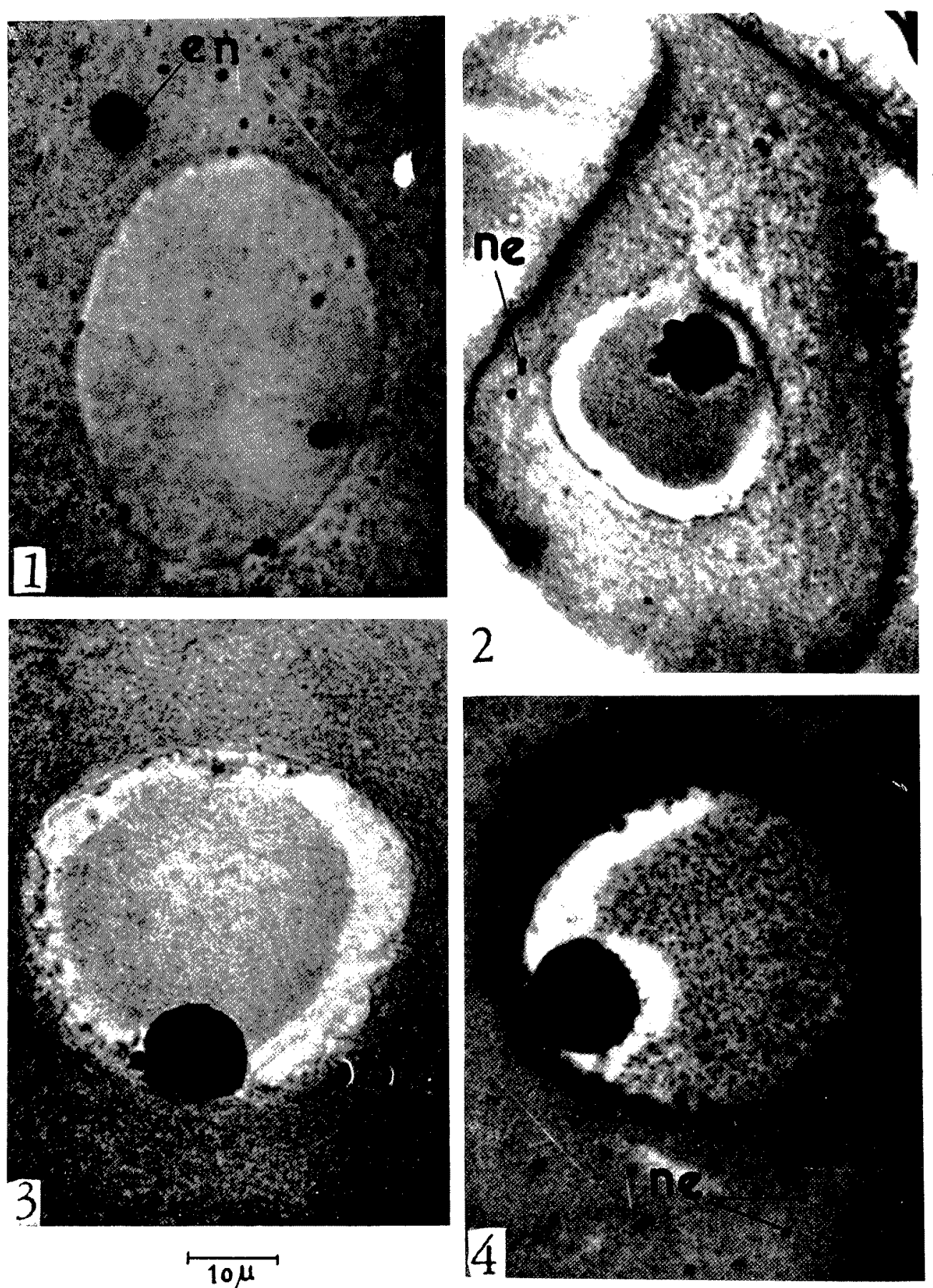

Figs. 1-4. 1, Buthus hendersoni, Rossman/PAS. 2, B. hendersoni, Carnoy/haematoxylin. 3, B. macmahoni, Carnoy/toluidine blue at $\mathrm{pH} 4.2 .4, B$. tamulus, WB $+\mathrm{PE} / \mathrm{AH}$. 

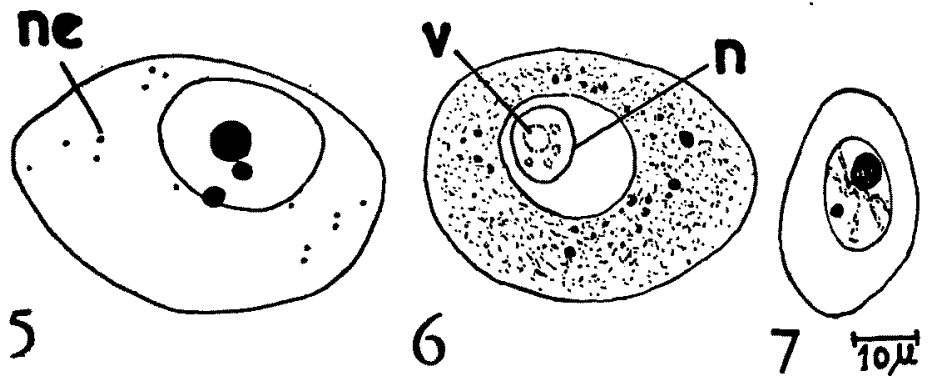

en
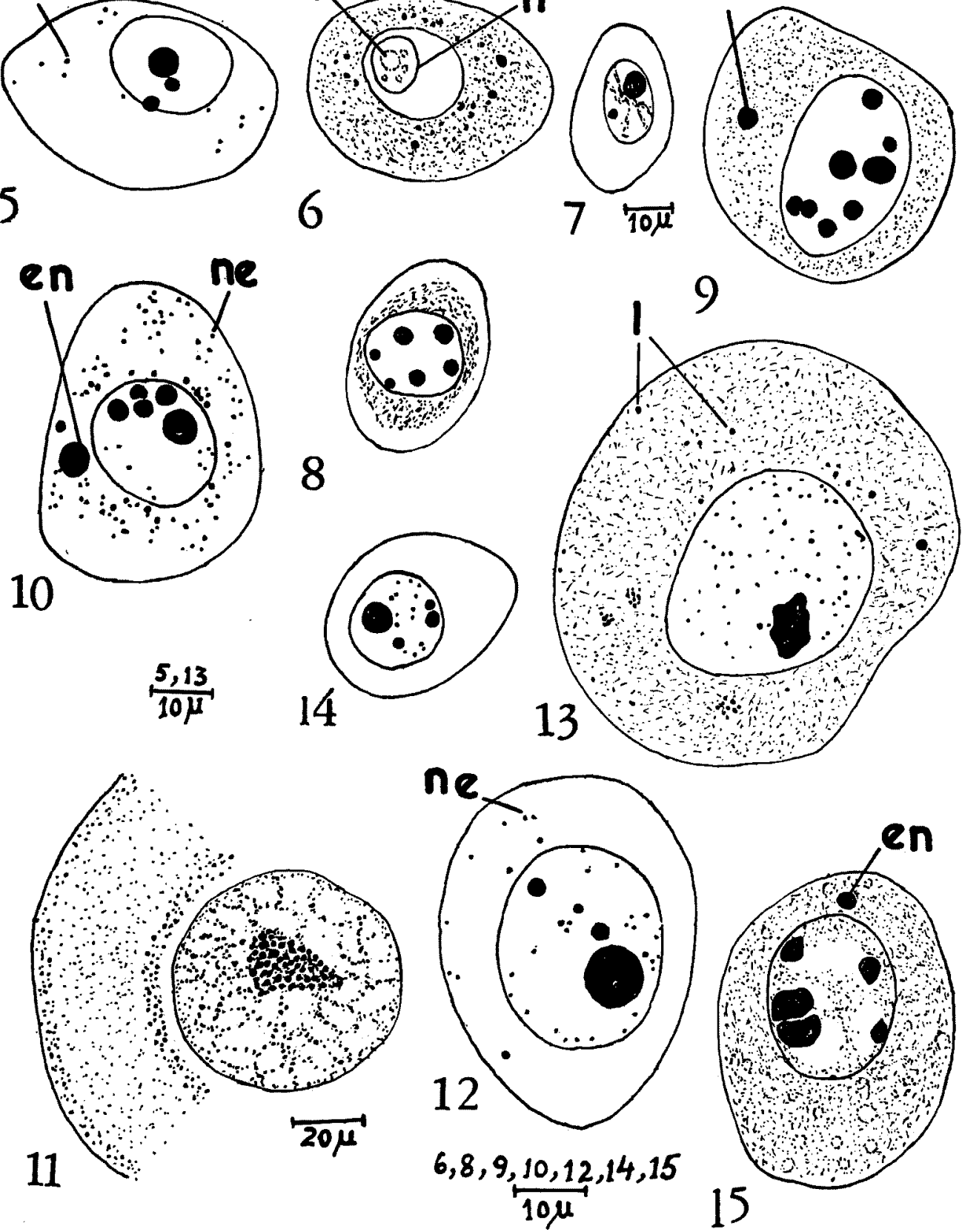

Figs. 5-15. 5, Palamnaeus fulvipes, Zenker/haematoxylin. 6, Argas persicus, FCa+PC/SBB. 7, A. persicus, Zenker/toluidine blue, $\mathrm{pH}$ 4.2. 8-9, H. aegyptium, $\mathrm{FCa}+\mathrm{PC} / \mathrm{AH} .10, H$. aegyptium, Canroy/haematoxylin. 11, Lycosa chaperi, Zenker/CTZ. 12, Crossopriza lyoni, Zenker/haematoxylin. 13, Melanopa unicolor, FCa $+\mathrm{PC} / \mathrm{AH}$. 14, Diplotemnus insolitus, Carnoy/Feulgen. 15, Zenker MG-PG. Abbreviations: en, extruded nucleolus. 1, lipids. n, nucleolus. ne, nucleolar extrusions, $v$, vacuole. 
The nucleolar extrusions disappear at the beginning of yolk formation which first appears at the peripheral ooplasm.

In $L y \cos a$ the nucleoli vary in size from 2.7 to $11.5 \mu$ in the developing oocytes measuring 23.0 to $54.5 \mu$. In young oocytes five to six small nucleoli are usually observed. In a slightly grown up oocyte (Fig. 11) there is left a single large heterogeneous nucleolus which is of irregular shape. It seems to be formed of aggregation of small and large spherules.

In Crossopriza there is a single nucleolus measuring 4.0 to $14.0 \mu$ in the developing oocytes measuring 120.0 to $410.0 \mu$. The nucleolus buds off extrusions (Fig. 12) which remain in the vicinity of the germinal veiscle in the ooplasm and disappear as soon as the yolk globules have appeared.

In Melanopa, the single nucleolus measures 4.2 to $10.0 \mu$ in the developing oocytes measuring 14.4 to $57.6 \mu$ (Fig. 13). The nucleolus buds off small granules in the young oocytes. The granular buds disappear when the yolk spheres appear in the ooplasm.

In Diplotemnus five to six nucleoli measuring 2.0 to $3.7 \mu$ have been observed in the developing oocytes measuring 20.0 to $80.0 \mu$ (Figs. 14, 15). Two types of nucleoli have been identified, i) Feulgen positive (Karyosomes of other workers) and ii) Feulgen negative (plasmosomes of other workers) (Wilson 1928, Duryee 1950).

In all the species investigated the nucleoli show intense positive reactions for proteins and RNA. They also show positive tests for carbohydrates, DNA and phospholipids. The nucleoli in Buthus, Hyalomma, Argas, Lycosa, Crossopriza and Melanopa, show slight positive test for alkaline phosphatase. The nucleoli in Buthus contain tyrosine, arginine, SH groups; in Palamnaeus and Lycosa, tryosine, tryptophan. SH groups; in Crossopriza, tyrosine, tryptophan, histidine, arginine, SH groups; in Hyalomma and Argas, tyrosine, $\mathrm{SH}$ groups; in Melanopa, tyrosine, tryptophan, histidine, SH groups. In Diplotemnus both the types of nucleoli show positive tests for RNA, proteins (tyrosine, arginine, SH groups) and give slightly positive tests for carbohydrates. In almost all the species the nucleoli are positive to $\mathrm{CTZ}$ reaction even after benzoylation control. According to Mitchell (1942) and Danielli $(1947,1950)$ the positive tetrazonium reaction of benzyolated tissues is due to purine and pyrimidine containing compounds (For detailed reactions refer to the table).

In all the species the nucleoli appear to be active only in the early stages of vitellogenesis. The nucleoli are vacuolated in the young oocytes. The vacuoles are negative to all the histochemical tests. Often the nucleolus takes its position close to the nuclear membrane in the germinal vesicle (Fig. 4). In Buthus, Hyalomma, and Diplotemnus, sometimes, the nucleolus has been seen lying in the ooplasm close to the nuclear membrane (Figs. 9, 10, 15). There is no direct connection between the nucleolar extrusions and the yolk globules. 


\section{Discussion}

The nucleoli in the oocytes of Buthus, Hyalomma, Argas, Lycosa, Crossopriza, Melanopa and Diplotemnus are quite large and play an active part in the growth of young oocytes. They emit nucleolar extrusions. In Palamnaeus, however, the small nucleolus rarely shows nucleolar extrusions. There is no direct evidence of the nucleolar extrusions giving rise to yolk bodies; nevertheless there is evidence that nucleolar extrusions, rich in RNA and proteins appear at an earlier stage than the yolk bodies. Recently, Gresson and Threadgold (1962) have demonstrated the extrusion of nuclear material during oogenesis in Blatta orientalis. They have concluded that the emission of material from the nucleolus and the passage of vesicles from the nuclear membrane to the cytoplasm are necessary prerequisites for the process of vitellogenesis'. In all the species the nucleoli show positive reactions for proteins and RNA. In certain cases, they also show positive tests for carbohydrates. phospholipids. DNA and alkaline phosphatase. This is in conformity with other workers (Vincent 1955. Brach?: 196). Sirli. 1961). Nucleoli in frog oocytes, occasionally when they are in close contact with the nuclear membrane evert their contents, which in turn pass into the cytoplasm (Brachet 1957). Sirlin (1961) has postulated the nucleolar contribution in RNA, proteins and enzymes to the cell metabolism. According to Brachet (1957) often the extrusion of whole nucleolus is the result of a pinching off of the nuclear membrane. Wischnitzer (1960) remarks that the extrusion of nucleoli may be specialized mechanisms called into action only ai times of great metabolic activity.

Two types of nucleoli, i) Feulgen posicive and ii) Feulgen negative, have been identified in Diplotemnus oocytes. The Feulgen positive nucleoli contain DNA. proteins (tyrosine, arginine, SH groups), RNA and traces of carbohydrates. The Feulgen negative nucleoli have a similar chemical composition as the Feulgen positive ones, except that the former do not contain DNA. Kobayashi (1954) identified two types of nucleoli, 1) Karyosomes (K) and 2) Plasmosomes (P) in the eggs of Ostrea. Kobayashi observed that $\mathrm{K}$ includes DNA and $\mathrm{P}$ includes RNA, $\mathrm{K}$ contains much volume of arginine but $\mathrm{P}$ does not; $\mathrm{P}$ contains some of histones type proteins. He remarks that the substances which are called nucleolus in general are not the same one from chemical view points but differ according to the kind of the cell and to the species of the animals.

Thanks are due to Professor G.P. Sharma, Head of the Zoology Department, Panjab University for laboratory facilities, to Professor Vishwa Nath for guidance, and to Mr. P.K.B. Menon for helpful criticism.

\section{Summary}

1. The nucleoli in arachnids play an important role in the growth of young oocytes.

2. In Buthus, Hyalomma, Argas, Crossopriza and Melanopa they emit 
prominent nucleolar extrusions rich in ribonucleoproteins.

3. The nucleolar extrusions disappear before the appearance of yolk globules. However, the indirect participation of nucleolar extrusions in the yolk formation is not ruled out.

4. The nucleoli show intense positive test for RNA and proteins, and in some cases show slightly positive reaction for carbohydrates, phospholipids, DNA and alkaline phosphatase.

5. In Diplotemnus there are two types of nucleoli: i) Feulgen positive (Karyosomes of other authors) and ii) Feulgen negative (plasmosomes of other authors).

\section{References}

Alfert, M. and Geschwind, I.I. 1953. A selective staining method for the basic proteins of cell nuclei. Proc. Natl. Acad. Sci. 39: 991.

Baker, J.R. 1946. The histochemical recognition of lipine. Quart. J. micr. Sci. 87: 441.

- 1949. Further remarks on the Golgi element. Quart. J. micr. Sci. 90: 293.

- 1956. The histochemical recognition of phenol, especially tyrosine. Quart. J. micr. Sic. 97: 161.

Bradbury, S. 1956. Human saliva as a convenient source of ribonuclease. Quart. J. micr. Sci. 97: 323.

Brachet, J. 1957. 'Biochemical Cytology'. Academic Press.

- 1960. 'Biochemistry of Development'. Pergamon Press.

Caspersson, T. 1950. 'Cell Growth and Cell Function'. Norton, New York.

Duryee, W.R. 1950. Chromosomal physiology in relation to nuclear structure. Ann. N.Y. Acad. Sci. 50: 920.

Feulgen, R. and Rossenbeck, H. 1924. Z. phys. Chem., 135, 203. (Cited form Pearse, 1960).

Gelfant, S., Meyer, R.K. and Ris, H. 1955. Uterine growth following stimulation by estrogen and inhibition by aminopterin and nitrogen mustard. J. Exp. Zool. 128: 291.

Gomori, G. 1952. 'Microscopic Histochemistry'. Chicago.

Gresson, R.A.R. and Threadgold, L.T. 1962. Extrusion of nuclear material during oogenesis in Blatia orientalis. Quart. J. micr. Sci. 103: 141.

Hotchkiss, R.D. 1948. Arch. Biochem. 16: 13. (Cited from Pearse, 1960).

Jordan, B.M. and Baker, J.R. 1955. A simple pyronin/methyl green technique. Quart. J. micr. Sci. 96: 177.

Kobayashi, H. 1954. Cytochemical study on the nucleolus in the common Japanese oyster, Ostrea laperousi. II. Nucleic acids and nucleoprotein. J. Sci. Hiroshima Univ. 15: 1.

Korson, R. 1951. Differential stain for nucleic acids. Stain Tech. 26: 265.

Mazia, D., Brewer, P.A. and Alfert, M. 1953. The cytochemical staining and measurement of protein with bromphenol blue. Biol. Bull. 104: 57.

McManus, J.F.A. and Cason, J.E., 1950 J. Exp. Med. 91: 651. (Cited from Pearse 1960).

Mitchell, J.S. 1942. Brit. J. exp. Path. 23: 296. (Cited from Pearse. 1960).

Nath, V. 1925. Cell inclusions in the oogenesis of scorpions. Proc. Roy. Soc. B98: 44.

Pearse, A.G.E. 1960. 'Histochemistry'. London (Churchill).

Sareen, M.L. 1961. Morphological and cytochemical studies on the female germ cells of the scorpions, Buthus hendersoni Pocock, and B. macmahoni Pocock. Res. Bull. Panjab Univ. 12: 221.

- 1962. Morphological and histochemical studies on the female germ cells of scorpions, Palamnaeus fulvipes Koch and $P$. bengalensis Koch. Res. Bull. Panjab Univ. 13: 73.

- 1963. Cytochemical studies on the female germ cells of Melanopa unicolor. Res. Bull. Panjab Univ. 14: 273.

- 1964. Cytochemical studies on the female germ cells of Lycosa chaperi Simon (Araneae: Lycosidae). Res. Bull. Panjab Univ. 16: 105.

- 1965a. Cytochemical studies on vitellogenesis in the spider, Crossopriza lyoni. Res. Bull. Panjab Univ. 16: 1. 
- 1965b. Histochemical studies on the female germ cells of the pseudoscorpion, Diplotemnus insolitus Chamberlin (Chelonethida: Atemnidae). Res. Bull. Panjab Univ. 16: 9 .

- 1965c. Morphological and cytochemical analysis of the female germ cells of the ticks Argas persicus (Oken) and Hyalomma aegyptium (Linn.). Res. Bull. Panjab Univ. 16: 31 .

Sirlin, J.I. 1960. The nucleolus of the cell nucleus. Endeavour 20: 146.

Swift, H. 1958. 'The chemical Basis of Development'. John Hopkins Press, Baltimore.

Wilson, E.B. 1928. 'The Cell in Development and Heredity'. MacMillan Co., New York.

Wischnitzer, S. 1957. The ultrastructure of yolk platelets of amphibian oocytes. J. Biophys. Biochem. Cytol. 3: 1041. 